METALLURGY AND FOUNDRY ENGINEERING - Vol. 34, 2008, No. 1

\author{
Mohammad Hassan Joulazadeh*
}

\title{
ENVIRONMENTAL FRIENDLY CONSUMPTION OF SCRAP TIRES IN EAF'S TO SAVE POWER \& CARBON
}

\section{INTRODUCTION}

The Islamic Rep. of Iran began to produce steel about 40 years ago. Figure 1 shows crude steel production trend in Iran. Iran produced 10,2 mmt crude steel in 2007. EAF steelmaking routes share is $77.5 \%$, for the $4^{\text {th }}$ development plan this share will increase up to $85 \%$. Iranian steelmaking inputs are DRI (65\%), HM (20.5\%) and Scrap (14.5\%) which differ from world steelmaking inputs. Carbon is one of the most utilized compounds in EAF steelmaking and plays a significant role in the process as follows.

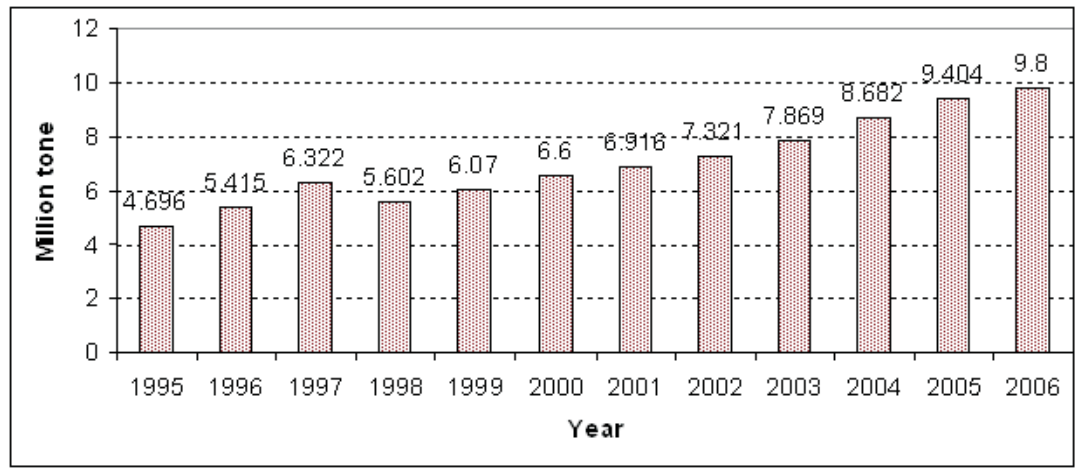

Fig. 1. Iranian crude steel production trend

- Source of energy in the steel bath via reaction with oxygen

$2 \mathrm{C}+\mathrm{O}_{2} \rightarrow 2 \mathrm{CO}$

* M.Sc.: Persia Metal Co. Consultant, Esfahan, Islamic Republic of Iran; e-mail: joulazadeh@pmco.ir 
- Source of energy above the bath via post combustion with oxygen

$$
\mathrm{CO}+\mathrm{O}_{2} \rightarrow \mathrm{CO}_{2}
$$

- Recovery of iron from the slag via the reaction

$$
\mathrm{FeO}+\mathrm{C} \rightarrow \mathrm{Fe}+\mathrm{CO}
$$

- Slag foaming materials.

- Fundamental alloying element.

The amount of charge carbon used depends on several factors including.

- Carbon content of scrap charge.

- Desired tapping carbon

- Projected oxygen gas consumption.

- The economics of iron yields versus $C$ cost [1].

In the past carbon bearing materials were charged into EAF to ensure that the melt-in carbon level was about that desired in the final product. Carbon bearing materials used normally for EAF are metallurgical, petroleum, fluid coke, anthracite coal and artificial graphite. Iranian EAF units mostly used coke or coal as carbon bearing materials usually, these materials imported from abroad. The price of coke and clean coal varies between 300$350 \$ /$ t. On the other hand about 8 millions passenger car and truck tires scrapped each year usually spread in land. In this situation ESCo decided to improve the environment by recycling scrap tires instead of burying them in landfills and reduce steelmaking cost. ESCo first pondered waste tire as a recyclable material in 2004. Since then, these resources have been in use as a partial steel scrap and coke replacement within EAF steelmaking. While use of tires in EAFs is a new market in IRI, this practice was is standard in US and France in 2000, in Japan 1998. Now in Japan, some $15 \%$ of all used tires are consumed by EAFs. In the US in 2005, 1.34 million (18880 tons) waste tires were consumed by EAF [2]. This research is related to the melting of scrap metal in various Iranian EAF, using whole used tires as an additional source of heat and carbon. Some of worldwide steel companies such as West Siberian I\&S works \& Nippon Steel use scrap tires in oxygen blown vessels successfully.

\section{ENVIRONMENT AND SCRAP TIRES}

In 2006 more than 1.3 billion scrap tires were generated in the US, Japan, Russia, Iran and they discard 300 [2], 130, $50 \& 8$ million truck and passenger car tires per year respectively. Scrap tires are a significant problem worldwide and their disposal presents environmental and safety hazards including fire, overflowing landfills and pollution of the atmosphere. Disposal of scrap tires in tire piles is non-acceptable practice because of the risks posed by tire fire and because tire piles can provide habitats for disease vector such as mosquitoes [3]. Tire stock piles host snakes and small mammals such as rats, opossum, skunks and raccoons. The greatest risk associated with scrap tire stockpiles is their possible ignition. Once ignited, stock pile fires tend to spread rapidly generating massive quantities of smoke and contaminated water. In recent years 7 scrap tire stock piles fired in the Tehran, Qazvin, Eslam Shahr, Karaj and Yazd cities of Iran. It is reported that in 1983 a 7 million 
tire fire in Rhinehart Virginia issued a cloud of smoke with air pollution deposited in three states. In 1999 a lighting strike ignited tire fire in Westley, California [4]. ESCo took environmental responsibilities very seriously and tried to help and to solve environmental problems and get economical and ecological benefits from scrap tires. For this purpose ESCo began to use its scrap tires collected in sto-

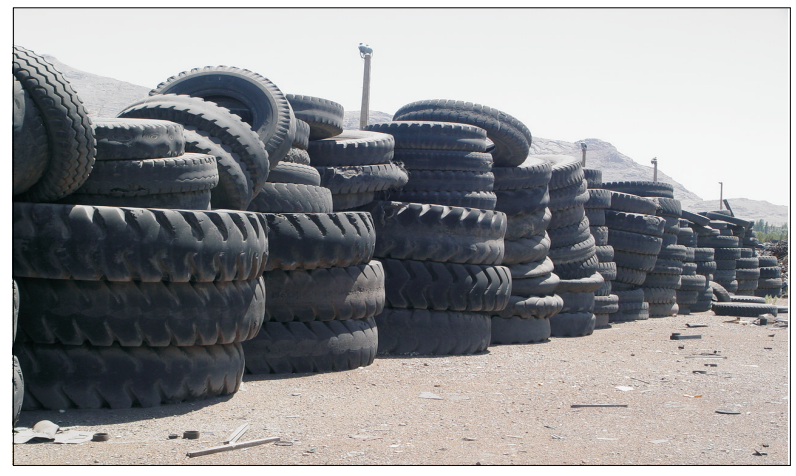

Fig. 2. A view of ESCos scrap tires storage rage, in the EAF. Figure 2 presents a view of ESCo's scrap tires storage. The scrap automotive tires are so plentiful that they have a near zero cost.

\section{PRERESEARCH}

Before using worn-out tires in EAF, research was done to determine results for using old tires in other industrial fields. Cement kilns, boilers, pulp and paper mills were used for discarding tires. Except for cement kilns, old tires are not readily acceptable for use as energy source [5]. Size and steel belts and beads of tires can be problematic for some scrap tires uses, but belts and beads are valuable raw materials for steel mill using EAF. In this research in the first step ESCos scrap tires storage was visited and the number, type and weight of them determined. The weight of them varied between 5 up to $1000 \mathrm{~kg}$. For the calculation of steel bead weight, 7 pieces of passenger car tires were completely burned and it was found that scrap tires contain $10 \%$ bead. Steel grade of bead was C67. The heat of combustion of scrap tire was $8334 \mathrm{kcal} / \mathrm{kg}$.

\subsection{Trials in 6 tons capacity EAF}

Initial trials were done in the melt shop employing a $6 \mathrm{Mg}$ AC EAF for casting parts manufacturing. The EAF powered by a 2.8 MVA transformer. All scraps and fluxes are delivered via a single basket. Produced steel grades are shown in the Table 1 . The details of heats parameters are illustrated in Table 2 . As shown in the Table 2 approximately $16 \mathrm{~kg}$ scrap tire/t is consumed. S content of steels was lower then limited value. Coke and pig iron charges (as carbon sources) were eliminated. Electrical energy consumption was reduced as compared to nominal and actual rate by $10 \& 12 \%$ respectively. As shown in Figure 3 actual electric energy consumption decreased from 448 to $388 \mathrm{kWh} / \mathrm{Mg}$ steel. Carburizing of steel (up to $1 \% \mathrm{C}$ ) was done by scrap tires. Production cost was lowered by $4-5 € / \mathrm{Mg}$. In the flue gas $\mathrm{CO}, \mathrm{NO}_{\mathrm{x}}$ and $\mathrm{SO}_{2}$ content was lower than permitted range (measured by the Testo 350XL). Table 3 shows comparison of flue gas composition analyzed and allowed. The heat results of EAF (6t) did not reveal any difference between carbon from coke, coal, pig iron and that from scrap whole tires. In this step of research more than $300 \mathrm{Mg}$ casting parts was manufactured and totally $4.5 \mathrm{Mg}$ of scrap tires consumed, which corresponds to two passenger car tires/t charged. The used tires were charged as whole to scrap basket near the bottom 
of metallic charge. Steel scrap is added onto the tires, which compresses tires and decreases the space occupied by them. Figure 4 presented charging of scrap tires in scrap bucket. Adding of scrap tires to molten steel is dangerous and not recommended.

Table 1. Steel grades heats produced with charging scrap tires

\begin{tabular}{|c|c|c|c|c|c|c|c|c||}
\hline Grade & $\mathbf{C}$ & $\mathbf{M n}$ & $\mathbf{S i}$ & $\mathbf{P} \leq$ & $\mathbf{S} \leq$ & $\mathbf{C r}$ & $\mathbf{N i}$ & $\mathbf{M o}$ \\
\hline 20GL & $0.15-0.25$ & $1.20-1.50$ & $0.20-0.42$ & 0.040 & 0.040 & $\leq 0.30$ & $\leq 0.30$ & \\
\hline GS-45 & $0.20-0.25$ & $0.60-1.00$ & $0.35-0.60$ & 0.030 & 0.030 & $\leq 0.40$ & $\leq 0.40$ & \\
\hline 25L & $0.22-0.30$ & $0.30-0.75$ & $0.20-0.42$ & 0.040 & 0.045 & $\leq 0.30$ & $\leq 0.30$ & \\
\hline 30L & $0.27-0.34$ & $0.30-0.75$ & $0.20-0.42$ & 0.040 & 0.040 & $\leq 0.30$ & $\leq 0.30$ & \\
\hline 35L & $0.32-0.40$ & $0.40-0.90$ & $0.20-0.42$ & 0.040 & 0.045 & $\leq 0.30$ & $\leq 0.30$ & \\
\hline 45L & $0.42-0.50$ & $0.40-0.90$ & $0.20-0.42$ & 0.040 & 0.045 & $\leq 0.30$ & $\leq 0.30$ & \\
\hline WS-140 & $0.67-0.75$ & $0.72-0.78$ & $0.47-0.53$ & 0.030 & 0.030 & $2.22-2.28$ & $\leq 0.30$ & $0.30-0.40$ \\
\hline WS-170 & $0.80-0.90$ & $0.70-1.20$ & $0.30-0.60$ & 0.045 & 0.045 & $2.00-2.40$ & $\leq 0.50$ & $0.30-0.45$ \\
\hline 38KhGN & $0.35-0.43$ & $0.8-1.10$ & $0.20-0.42$ & 0.040 & 0.040 & $0.50-0.80$ & $0.70-1.00$ & \\
\hline 30KhN2M & $0.27-0.34$ & $0.30-0.60$ & $0.17-0.37$ & 0.020 & 0.020 & $0.60-0.90$ & $1.30-1.70$ & $0.20-0.30$ \\
\hline 30Kh & $0.65-0.75$ & $0.40-0.90$ & $0.20-0.42$ & 0.035 & 0.035 & $0.80-1.10$ & $\leq 0.40$ & \\
\hline GS-20Mn5 & $0.17-0.23$ & $1.00-1.50$ & $\leq 0.60$ & 0.020 & 0.015 & $\leq 0.30$ & $\leq 0.40$ & $\leq 0.15$ \\
\hline 6KhGNM2 & $0.50-0.60$ & $1.00-1.20$ & $0.40-0.60$ & 0.040 & 0.040 & $2.40-2.60$ & $0.70-0.90$ & $0.40-0.60$ \\
\hline
\end{tabular}

Table 2. Details of some heat parameters

\begin{tabular}{||c|c|c|c|c|c|c||}
\hline $\begin{array}{c}\text { Final } \\
(\mathbf{C \%})\end{array}$ & $\mathbf{C \%}$ & $\begin{array}{c}\text { En.Con. } \\
(\mathbf{k W h} / \mathbf{t})\end{array}$ & $\begin{array}{c}\text { Scrap Tire } \\
(\mathbf{k g})\end{array}$ & $\begin{array}{c}\text { Final } \\
(\mathbf{S \%})\end{array}$ & Grade & $\begin{array}{c}\text { Heat } \\
\#\end{array}$ \\
\hline 0.37 & $0.32-0.40$ & 387.6 & 59 & 0.022 & $35 \mathrm{~L}$ & 20748 \\
\hline 0.66 & $0.65-0.75$ & 387 & 76 & 0.026 & WS-140 & 20751 \\
\hline 0.72 & $0.65-0.75$ & 333.5 & 125 & 0.015 & WS-140 & 20760 \\
\hline 0.37 & $0.32-0.40$ & 389.9 & 90 & 0.027 & $35 \mathrm{~L}$ & 20762 \\
\hline 0.70 & $0.65-0.75$ & 416.8 & 125 & 0.010 & WS-140 & 20763 \\
\hline 0.31 & $0.27-0.34$ & 312.8 & 80 & 0.022 & $30 \mathrm{~L}$ & 20765 \\
\hline 0.30 & $0.32-0.40$ & 457 & 100 & 0.022 & $35 \mathrm{~L}$ & 20766 \\
\hline 0.49 & $0.42-0.50$ & 345.9 & 100 & 0.027 & $45 \mathrm{~L}$ & 20767 \\
\hline 0.69 & $0.65-0.75$ & 407.6 & 135 & 0.015 & WS-140 & 20768 \\
\hline 0.83 & $0.75-0.85$ & 384 & 150 & 0.011 & WS-170 & 20771 \\
\hline 0.66 & $0.65-0.75$ & 467.7 & 150 & 0.015 & WS-140 & 20773 \\
\hline 0.29 & $0.27-0.34$ & 404.7 & 110 & 0.018 & $30 \mathrm{~L}$ & 20774 \\
\hline 0.73 & $0.65-0.75$ & 390.2 & 160 & 0.020 & WS140 & 20789 \\
\hline 0.28 & $0.27-0.34$ & 374.4 & 100 & 0.020 & $30 \mathrm{~L}$ & 20790 \\
\hline 0.45 & $0.42-0.50$ & 420.7 & 130 & 0.026 & $45 \mathrm{~L}$ & 20791 \\
\hline 0.37 & $0.35-0.42$ & 353.6 & 120 & 0.025 & $38 \mathrm{KhGN}$ & 20792 \\
\hline 0.45 & $0.42-0.50$ & 360 & 130 & 0.015 & $45 \mathrm{~L}$ & 20793 \\
\hline 0.43 & $0.42-0.50$ & 317.5 & 130 & 0.022 & $45 \mathrm{~L}$ & 20795 \\
\hline 0.71 & $0.65-0.75$ & 381.8 & 160 & 0.015 & WS140 & 20796 \\
\hline 0.36 & $0.32-0.40$ & 397.8 & 110 & 0.020 & $35 \mathrm{~L}$ & 20798 \\
\hline 0.36 & $0.32-0.40$ & 322.6 & 100 & 0.021 & $35 \mathrm{~L}$ & 20806 \\
\hline 0.27 & $0.22-0.30$ & 341.7 & 70 & 0.024 & $25 \mathrm{~L}$ & 20809 \\
\hline 0.36 & $0.32-0.40$ & 360 & 100 & 0.026 & $35 \mathrm{~L}$ & 20812 \\
\hline 0.40 & $0.42-0.50$ & 338.5 & 120 & 0.021 & $45 \mathrm{~L}$ & 20813 \\
\hline 0.22 & $0.20-0.25$ & 453.6 & 150 & 0.025 & GS-45 & 20815 \\
\hline 0.04 & $0.42-0.50$ & 391.4 & 100 & 0.029 & $45 \mathrm{~L}$ & 20817 \\
\hline 0.36 & $0.32-0.40$ & 346 & 100 & 0.021 & $35 \mathrm{~L}$ & 20829 \\
\hline
\end{tabular}




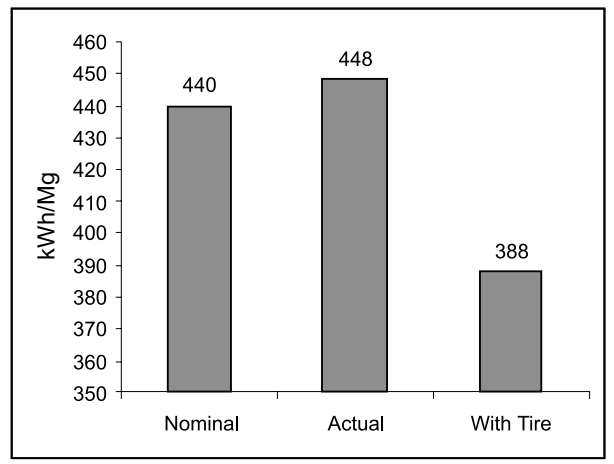

Fig. 3. Influence of scrap tires used on electrical energy consumption

Table 3. $\mathrm{CO}, \mathrm{NO}_{\mathrm{x}}$ and $\mathrm{SO}_{2}$ content of flue gas

\begin{tabular}{|c|c|c|c|c|c|c|c|c|c|c|c|c|}
\hline \begin{tabular}{|l|} 
Heat \# \\
20930 \\
\end{tabular} & $\begin{array}{l}\text { Heat \# } \\
20929 \\
\end{array}$ & $\begin{array}{l}\text { Heat \# } \\
20922\end{array}$ & $\begin{array}{l}\text { Heat \# } \\
20921 \\
\end{array}$ & \begin{tabular}{|l|} 
Heat \# \\
20844 \\
\end{tabular} & \begin{tabular}{|c|} 
Heat \# \\
20817 \\
\end{tabular} & $\begin{array}{c}\text { Heat \# } \\
20815\end{array}$ & $\begin{array}{l}\text { Heat \# } \\
20796 \\
\end{array}$ & \begin{tabular}{|c|} 
Heat \# \\
20774 \\
\end{tabular} & $\begin{array}{c}\text { Heat \# } \\
20738 \\
\end{array}$ & $\begin{array}{c}\text { Allowed } \\
\text { Range }\end{array}$ & Unit & Gas \\
\hline 87 & 297 & 178 & 180 & 435 & 110 & 144 & 114 & 129 & 128 & 435 & PM & $\mathrm{CO}$ \\
\hline 11.79 & 42 & 72 & 87 & 84 & 0.5 & 36 & 158 & 128 & 126 & 350 & PPM & $\mathrm{NO}_{\mathrm{X}}$ \\
\hline 16.7 & 9.5 & 25 & 6.8 & 56 & 0 & 15 & 11 & 19 & 19 & 800 & PPM & $\mathrm{SO}_{2}$ \\
\hline
\end{tabular}

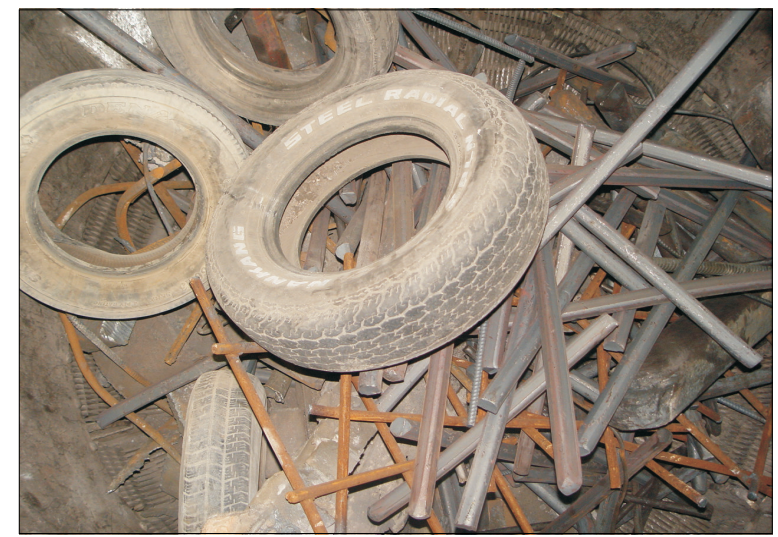

Fig. 4. Charging of scrap tires in scrap basket

\subsection{Performance of Used Tires in $40 \mathrm{Mg}$ AC EAF}

After observing successful results in $6 \mathrm{Mg}$ capacity AC EAF, we decided to perform this work in a high capacity EAF in IAS Co. This plant has two $40 \mathrm{Mg}$ AC EAF, two ladle stirring station and a 4 strand billet CCM. The EAF is powered by two 30 MVA transformers and a co-jet slag door burner device equipped with post combustion oxygen port. It makes 
between 14-15 heats per day. 20 heats were made with 11571 and 00601 steel grades. Metallic materials were charged into EAF in 2 or 3 baskets. The first basket contained more used tires than the second one, and the second more than third. For safety purpose after each tapping $40-50 \%$ of required lime was charged on the bottom of EAF. Scrap tires were put in the middle of each basket. Once the steel scrap charge was molten, pure oxygen was injected by lance to create decarburization and post combustion of the excess CO. Scrap tires added with the iron bearing charge give additional energy by exothermic reactions [6].

$$
\begin{array}{ll}
\text { Decarburizing } & \mathrm{C}+\mathrm{O}_{2} \rightarrow \mathrm{CO}+1.35 \mathrm{kWh} / \mathrm{kg} . \mathrm{C} \\
\text { Post combustion } & \mathrm{CO}+\mathrm{O}_{2} \rightarrow \mathrm{CO}_{2}+6.0 \mathrm{kWh} / \mathrm{kg} . \mathrm{C} \\
\text { Total } & \mathrm{C}+\mathrm{O}_{2} \rightarrow \mathrm{CO}_{2}+7.35 \mathrm{kWh} / \mathrm{kg} . \mathrm{C}
\end{array}
$$

A general trend observed for EAF processes is an increase in oxygen and carbon injections. Results of this work were as follows:

- Coke is replaced by scrap tires and coke consumption completely eliminated.

- Average scrap tires consumption was $14.1 \mathrm{~kg} / \mathrm{t}$.

- Electric power consumption decreased by $10 \%$ (from 580 to $530 \mathrm{kWh} / \mathrm{Mg}$ ) and production cost lowered by $5 € / \mathrm{t}$. $\mathrm{CO}, \mathrm{SO}_{2}$ and $\mathrm{NO}_{\mathrm{x}}$ content of stack gas was within allowed range.

- Similar results were obtained in Malayer alloy steel company with 25 t EAF (17 MVA).

\subsection{Dioxins Formation \& Emissions}

Of the various pollutants generated in EAF steelmaking processes, dioxins are by far the most toxic. The problem of dioxins emissions is particularly critical in EAF units where large quantities of externally purchased scrap (with the omnipresent organic \& chloride compounds) are melted to produce steel [7]. Poly Chloral Dibenzol Dioxins are chemical compounds of chlorine. A dioxin is any compound that contains the dibenzo-p- dioxin nucleus. A furan is any compound that contains the dibenzofuran nucleus [8]. The general formulas are shown in Figure 5. According to information from Rubber Manufacturers Association, tires contain nearly undetectable level of chlorine and do not from dioxins in high temperature processes [5]. No influence on measured concentration of dioxins and furan in the gaseous phase in smokestack emissions of EAF steelmaking with scrap tire charge mix was found [6]. A number of factors influence the amount of dioxins which may be formed in a given EAF steelmaking process, including temperature, $\mathrm{pH}$, catalyst and reactions kinetics. The effect of temperature on formation of halogenated dioxins and furan is well recognized. A mathematical relationship between temperature and DXN formation has been proposed to calculate the theoretical amount of dioxins that can be expected (7).

$$
y=0.025 t^{2} e^{-3[(t-200) / 200]}
$$

where $\mathrm{y}$ is dioxin concentration $(\mathrm{ppb})$ and $\mathrm{t}$ is temperature $\left({ }^{\circ} \mathrm{C}\right)$. 

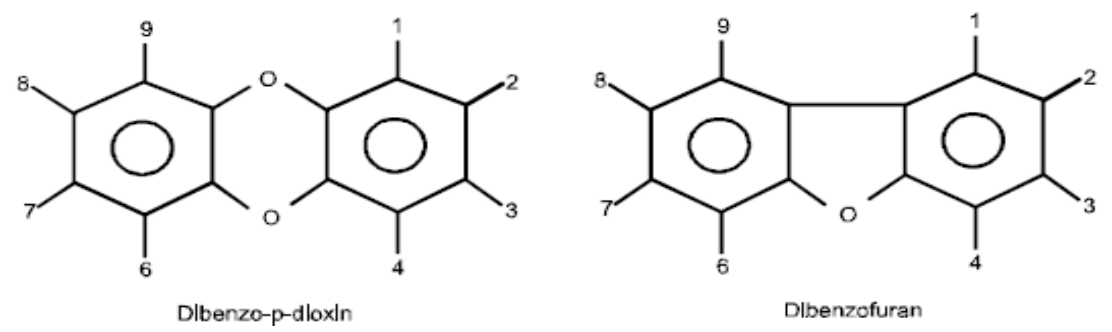

Fig. 5. General formulas of Dioxin (2, 3, 7, 8) \& Furan (2, 3, 7, 8) [8]

This relationship graphically represented in Figure 6, shows that dioxin formation peaks at $200^{\circ} \mathrm{C}$ and decreases unsymmetrically with increasing temperature [8]. If metallic charge of EAF contains some chlorine, in order to minimize the reforming of dioxin, rapid cooling of the process off gas to below $200^{\circ} \mathrm{C}$ is the most effective means [7]. Quality control of scrap or dust inputs depends on the process used. UNEP recommends an emission factor of $10 \mu \mathrm{g} T E Q / t \mathrm{ls}$. If controls are put on scrap to exclude cutting oils and heavily contaminated scrap, and gas cleaning with secondary combustion and fabric filtration are used, emissions below $0.1 \mu \mathrm{g}$ TEQ/tls can be achieved. Selection and sorting to prevent the addition of material that is contaminated with organic matter or precursors can reduce the potential for dioxin formation. The use of optimum combustion conditions and oxygen injection in the upper part of a furnace to ensure complete combustion of furnace gases may be necessary to achieve this. As the regulation values in EAF units in Japan are $0.5 \mathrm{ng}$ $\mathrm{TEQ} / \mathrm{Nm}^{3}$ or less for a newly built furnace, $5 \mathrm{ng}$ TEQ (Toxic Equivalency)/ $\mathrm{Nm}^{3}$ or less for an existing furnace. The temperature of the gas entering the bag house has strong effect on dioxin content discharged to atmosphere (see Fig. 7). When the temperature is kept below $80^{\circ} \mathrm{C}$, a dioxin content of less than $1 \mathrm{ng} \mathrm{TEQ} / \mathrm{Nm}^{3}$ can be achieved [9].

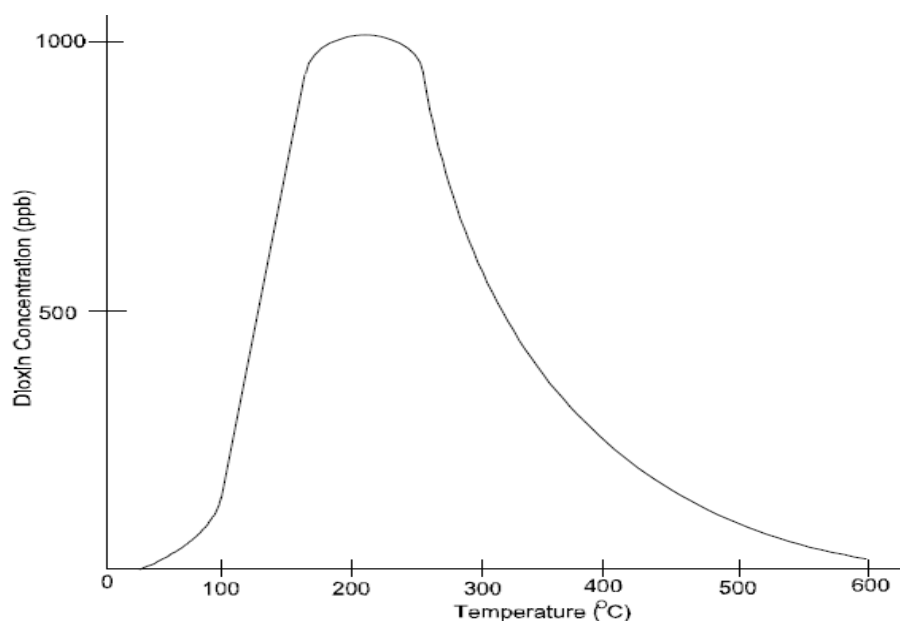

Fig. 6. Dioxine concentration versus temperature [8] 


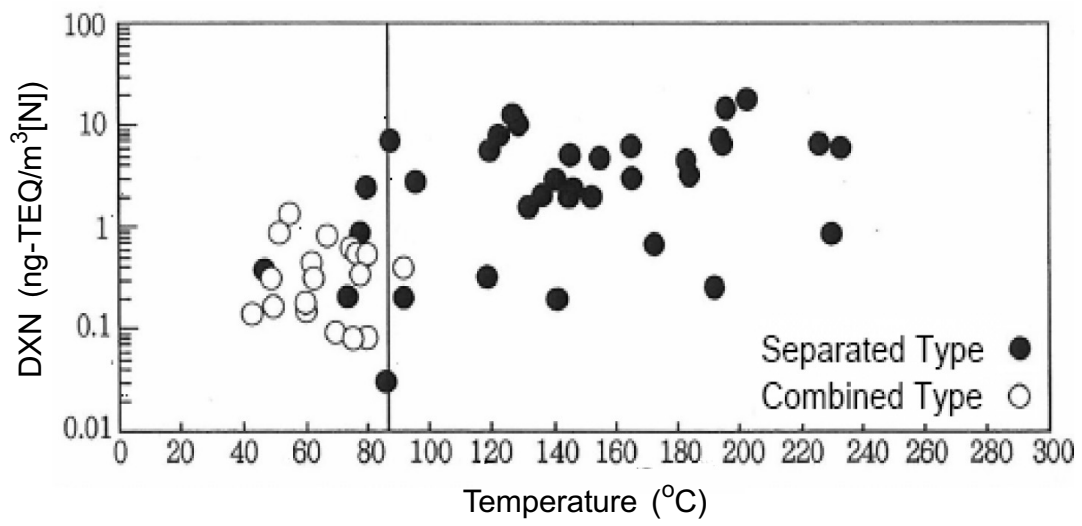

Fig. 7. Scatter plot of temperature of the inlet of dust collectors and DXN conc. in EAF flue gases [9]

\section{CONCLUSIONS}

This research has shown that scrap tires can be used as a substitute for carbon in the EAF steelmaking process. Used tires can replace coke in EAF at least up to the level $14.5 \mathrm{~kg} / \mathrm{Mg}$.

The replacement ratio is $1.6 \mathrm{~kg}$ tire $/ \mathrm{kg}$ coke. The tires are added to the scrap as a source of chemical energy.Replacing coal and coke consumption of used tires in EAF's resulted in the following:

1. Coke and coal charge are eliminated completely in $\operatorname{EAF}(6,25 \& 40 \mathrm{Mg})$ steelmaking process.

2. Rolling mills scale or oxygen gas are injected into EAFs while the scrap tires are burning so than combustion is complete and clean.

3. Bead wires ( $10 \%$ of tire weight) become a part of steel charge. Since the steel and other materials of tires are consumed, there is no ash or other waste.

4. Scrap tires are used as carbon source for low, medium and high carbon content steel as well as heat and wear resistant steels in EAF .

5. Consumption of scrap tires in EAF can provide a net decrease in electrical and chemical energy. In this research electrical energy consumption is reduced by $10-20 \%$.

6. The stack gas analysis has shown that the concentrations of $\mathrm{CO}, \mathrm{NO}_{\mathrm{x}} \& \mathrm{SO}_{2}$ were within permitted range.

7. No adverse impact on emissions and reduced $\mathrm{NO}_{\mathrm{x}}$ emission. $\mathrm{S}$ content of steel products was lower than $0.026 \%$.

8. Carburizing power of truck and bus tires is better than passenger car tires.

9. Adding of scrap tires to molten steel is not recommended.

10. The final cost of steel is lowered by $5 € / \mathrm{Mg}$.

11. In Iran annually 8 million passenger car and truck tires are discarded. In existing EAFs it is possible to use 11 millions scrap tires $(110000 \mathrm{Mg})$. Iran will produce 29 million tons of crude steel in $4^{\text {th }}$ development plan. In this case 40 millions passenger car tires or equal weight truck tires can be used in EAF steelmaking process. 
12. Mechanical, physical and chemical properties of steel products as well as gas content and absence of casting failures were approved by quality control department.

13. Using scrap tires is not recycling but it is considered as beneficial use. It is better to recover the energy from a tire rather than landfill it.

14. Scrap tires have a heat of combustion value of 6668 to $8355 \mathrm{kcals} / \mathrm{kg} \&$ contain less ash and $\mathrm{S}$ than most types of coals.

15. Shredding of tires is very expensive. In this research whole tires were charged into the EAF.

16. EAF can also accept large sized tires as bus, grader, mining and road machinery, bulldozer \& farm tires. In this respect a whole loader tires of $250 \mathrm{~kg}$ were charged into $40 \mathrm{Mg}$ EAF.

17. The low cost technique promotes environmental safety without affecting the steel quality.

18. According to information from Rubber Manufacturers Association, tires contain nearly undetectable levels of chlorine and do not form dioxin in high temperature process as EAF steelmaking. Dioxin formation peaks at $200^{\circ} \mathrm{C}$ and decreases unsymmetrically with increasing temperature. Tires have virtually no $\mathrm{Hg}$. In Japan, dioxins limited values are $0.5 \mathrm{ng}$ TEQ/ $\mathrm{Nm}^{3}$ or less for a newly built EAF and $5 \mathrm{ng} \mathrm{TEQ} / \mathrm{Nm}^{3}$ or less for an existing EAF.

\section{Acknowledgments}

This project is supported by ESCo. The Author would like to thank the managing director Mr. B. Sobhany, deputy managing director Mr. R.G. Ebrahimi and R\&D team of ESCo who cooperated and helped to conduct this work. Thanks are also extended to managing directors of Merat Poolad, Iran \& Malayer Alloy Steel companies for their kind cooperation to implement this environmental friendly research.

\section{REFERENCES}

[1] Jones J.A.T.: Carbon Utilization in the EAF, 1998, EAF conference proceeding, p. 599

[2] Rubber Manufacturing Association: Scrap tire markets in the U.S. 2005 Edition, Washington DC, 2006, p. 10

[3] EPA Management of Scrap Tires - Tire Derived Fuel, April 2005,EPA530-F-05-006 p. 1

[4] EPA Management of Scrap Tires - Tire fires

[5] Stebbing L.P.E.: Using scrap tires as a Chemical fuel source in the EAF. AISE, 2002, p. 3

[6] Clauzade/Aliapur C.: End of life tires in EAF-s: An industrial success story. 2006, p. 1

[7] Lehner J.: Low cost solutions for the removal of Dioxin from EAF off gas.Steel Times Int. September 2003, pp. $40-45$

[8] EPA-454/R-97-003: Locating and Estimating Air Emissions from Sources of Dioxins and Furans. U.S. Environment Protection Agency. Research Triangle Park, North Carolina 27711 May 1997, pp. 172-173(4)

[9] Yamakawa H., Isakara K. et al.: Study on dioxin reduction \& behavior of it in EAF. La Revue de Metallurgie, 2002 January, pp. 23-30

Received

October 2008 